\title{
Thermodynamic Calculation for Silicon Modified AISI M2 High Speed Tool Steel
}

\author{
Hossam Halfa \\ Steel Technology Department, Central Metallurgical R\&D Institute (CMRDI), Helwan, Egypt \\ Email: hossamhalfa@cmrdi.sci.eg
}

Received June 8, 2013; revised July 12, 2013; accepted July 23, 2013

Copyright (C) 2013 Hossam Halfa. This is an open access article distributed under the Creative Commons Attribution License, which permits unrestricted use, distribution, and reproduction in any medium, provided the original work is properly cited.

\begin{abstract}
During high speed tool steel production up to $0.2 \mathrm{wt} \%$ silicon is added, primarily to react with oxygen e.g. silicon acts as a de-oxidizer. If more than $0.2 \mathrm{wt} \%$ silicon is added, it serves to improve the deep hardening properties. An addition up to $\sim 1 \mathrm{wt} \%$ silicon provides hardness and improves temper-stability but reduces the ductility. At high concentration, silicon causes embrittlement. Alloying with silicon raises the solubility of carbon in the matrix and hence the as-quenched hardness. It has virtually no influence on the carbide distribution, but it promotes the formation of $\mathrm{M}_{6} \mathrm{C}$ type carbides. The many essential alloy additions to iron $(\mathrm{C}, \mathrm{W}, \mathrm{Mo}, \mathrm{V}, \mathrm{Cr}, \mathrm{Si})$ make the high speed tool steel, HSS a complex multi-component system. Its complete experimental investigation would require enormous time and effort. Instead, the CALPHAD method has been successfully used for computation of phase equilibrium the multi-component HSS system. In the present work, the Thermo-Calc program has been applied to the system Fe-C-Cr-W-Mo-V-Si with the thermodynamic information contained in the solid-solution-database of the TCFE. In the present work, some temperature-concentration diagrams for silicon modified AISI M2 steel are presented by calculated quantities (melting and transformation temperatures, amount and compositions of phases). Calculated data are compared with standard AISI M2 high speed tool steel.
\end{abstract}

Keywords: Phase Diagram; High Speed; Silicon; Carbides; Thermo-Calc

\section{Introduction}

High-speed steels are used for applications requiring long life at relatively high operating temperatures such as for heavy cuts or high-speed machining. High-speed steels are the most important alloy tool steels because of their very high hardness and good wear a resistance in the heat-reacted condition and their ability to retain high hardness and the elevated temperatures often encountered during the operation of the tool at high cutting speeds [1-3].

During steel production up to $0.2 \mathrm{wt} \%$ silicon is added, primarily to react with oxygen e.g. silicon acts as a deoxidizer. It makes steel sound, by removing oxygen bubbles from the molten steel. The percentage of silicon in the analysis was related to the type of steel, rimmed and capped steels (made by the ingot method) had no silicon intentionally added. Semi-killed steels typically contained up to $0.10 \%$ max silicon, and fully killed steels could have up to $0.60 \%$ maximum [4].

In addition to deoxidiation silicon also influences the steel five different ways [5]:
1) Silicon helps increase the steel's strength and hardness, but is less effective than manganese in these functions.

2) In electrical and magnetic steels, silicon helps to promote desired crystal orientations and electrical resistivity.

3) In some high temperature service steels, silicon contributes to their oxidation resistance.

4) In alloy grades, silicon also increases strength (but not plasticity) when quenched and tempered.

5) Silicon also has a moderate effect on harden ability of steel.

But there are always less desirable aspects of any element in an alloy

- Silicon is detrimental to surface quality in low carbon steels, a condition that is especially magnified in low carbon resulfurized steels.

- Silicon is detrimental to tool life in machining as it forms hard abrasive particles which increase tool wear and thus lower the steel's machinability.

The variety of the alloy additions occurring in the high-speed steels (C, W, Mo, V, Si, Cr, ) makes them the 
extraordinarily complex multi-phase system. The diversity of transformations, physical relationships, decides that their structural investigations call for using the most subtle investigation methods employed in the materials engineering.

Alloying with silicon raises the solubility of carbon in the matrix and hence the as-quenched hardness. It has virtually no influence on the carbide distribution [6], but it promotes the formation of $\mathrm{M}_{6} \mathrm{C}$ type carbides $[7,8]$.

In the present work, the Thermo-Calc program has been applied to the system Fe-C-Cr-W-Mo-V-Si with the thermodynamic information contained in the solid-solution-database of the TCFE. In the present work, some temperature-concentration diagrams for silicon modified AISI M2 steel are present and calculated quantities (melting and transformation temperatures, amount and compositions of phases). Calculated data are compared with standard AISI M2 high speed tool steel.

\section{Experimental Work}

\subsection{Melting and Casting}

To study the effect of silicon as alloying element, four alloying chemical composition range from $0 \mathrm{wt} \%$ silicon to $5 \mathrm{wt} \%$ silicon based on high speed tool steel AISI M2 were investigated. Five kilograms of each of the high speed tool steel AISI M2 alloys were melted from pure elements in a skull induction-melting furnace (ISM), which employed a water-cooled copper crucible. High purity argon was used as an inert gas, and titanium getters were melted to minimize interstitial gases including oxygen and nitrogen from the furnace atmosphere before melting.

New and developed batch of high speed tool steel AISI M2 was loaded into the skull induction melting furnace crucible under vacuum with pressure $1 \times 10^{-3}$ mbar. The entire crucible was inductively heated noting the power (based on voltage, current, and time at each setting) required for melting. The skull induction melting ingot was melted two times, inverting the ingot after each melting to ensure homogeneity. Cylindrical samples were obtained by drop casting into a $\mathrm{Cu}$-mould of diameter 60 $\mathrm{mm}$.

\subsection{Thermo-Calc Experimental}

The data for all edge binaries with $\mathrm{Fe}$ and $\mathrm{C}, \mathrm{Fe}-\mathrm{M}$, and $\mathrm{C}-\mathrm{M}$, as well as for ternaries Fe-C-M ( $\mathrm{M}=$ metal), are contained in the optimized TCFE database, together with data for other edge binaries and higher-order systems (M1-M2, M1-M2-C, M1-M2-Fe.). All phases in the database are described according to a sub-lattice model [9, 10]. Phases other than those in Table 1 have not been considered as possible stable phases in the calculations performed here, since they have not been reported in real high-speed-steel alloys.

It is important to mention that such a data base represents years of research with thousands of single measurements. The data base may be incomplete, or the models used to generate it may not be perfect, but it provides the most reliable prediction of phase relations available, though not the only possible ones.

\subsection{Testing}

The remelted ingots were cut in the longitudinal and transverse directions to physically examine the presence of any cavity or holes. All alloy samples under investigation were examined by radiographic tests to ensure that they were free from solidification defects.

Compositional analysis of the produced ingots was evaluated by standard gravimetric wet analytical techniques and further substantiated by induction-coupled plasma atomic emission (ICP-AES) technique. Carbon was analyzed using a gas analysis technique using a Leco

Table 1. Models of the phases considered in the calculations.

\begin{tabular}{|c|c|c|c|}
\hline Phase & Numbers of Sublattice & Numbers of Sites per Sublattice & Sublattice Species $(\mathrm{Va}=$ Vacancy) \\
\hline Liquid & 1 & 1 & $\mathrm{C}, \mathrm{Cr}, \mathrm{Fe}, \mathrm{Mo}, \mathrm{Si}, \mathrm{Co}, \mathrm{V}, \mathrm{W}$ \\
\hline FCC (austenite) & 2 & $1: 1$ & $\mathrm{Cr}, \mathrm{Fe}, \mathrm{Mo}, \mathrm{V}, \mathrm{W}: \mathrm{C}, \mathrm{Va}$ \\
\hline $\mathrm{BCC}$ (ferrite) & 2 & $1: 3$ & $\mathrm{Cr}, \mathrm{Fe}, \mathrm{Mo}, \mathrm{Si}, \mathrm{V}, \mathrm{W}: \mathrm{C}, \mathrm{Va}$ \\
\hline $\mathrm{MC}$ & 2 & $1: 1$ & $\mathrm{Cr}, \mathrm{Fe}, \mathrm{Mo}, \mathrm{V}, \mathrm{W}: \mathrm{C}, \mathrm{Va}$ \\
\hline $\mathrm{M}_{2} \mathrm{C}$ & 2 & $2: 1$ & $\mathrm{Cr}, \mathrm{Fe}, \mathrm{Mo}, \mathrm{V}, \mathrm{W}: \mathrm{C}, \mathrm{Va}$ \\
\hline $\mathrm{M}_{3} \mathrm{C}$ (cementite) & 2 & $3: 1$ & $\mathrm{Cr}, \mathrm{Fe}, \mathrm{Mo}, \mathrm{V}, \mathrm{W}: \mathrm{C}$ \\
\hline $\mathrm{M}_{6} \mathrm{C}$ & 4 & $2: 2: 2: 1$ & Fe: Mo, W:Cr, Fe, Mo, V, W:C \\
\hline $\mathrm{M}_{7} \mathrm{C}_{3}$ & 2 & $7: 3$ & $\mathrm{Cr}, \mathrm{Fe}, \mathrm{Mo}, \mathrm{V}, \mathrm{W}: \mathrm{C}$ \\
\hline $\mathrm{M}_{23} \mathrm{C}_{6}$ & 3 & $20: 3: 6$ & $\mathrm{Cr}, \mathrm{Fe}, \mathrm{V}: \mathrm{Cr}, \mathrm{Fe}, \mathrm{Mo}, \mathrm{V}, \mathrm{W}: \mathrm{C}$ \\
\hline
\end{tabular}


gas analyzer.

\subsection{Qualitative Carbide Description}

In order to determine the nature of the different carbides encountered in the studied material, a Nital (3\%) etching was made on a polished samples coming from the top and the bottom of the ingots were taken both at the center, half radius and the edge. The nature of the carbides is determined by means of electron microscopy (SEM and EDX), and the results are given in Table 2. It is well known that four groups of carbides were presence in HSS $\mathrm{M} 2: \mathrm{MC}$ (rich in $\mathrm{V}$ ), $\mathrm{M}_{2} \mathrm{C}$ (rich in $\mathrm{Mo}$ ), $\mathrm{M}_{6} \mathrm{C}$ (rich in $\mathrm{W}$ and $\mathrm{Mo}$ ) in addition to $\mathrm{M}_{7} \mathrm{C}_{3}$ and $\mathrm{M}_{23} \mathrm{C}_{7}$ carbides which rich in Cr. Furthermore, Groesbeck's reagent [11] was used to differentiate each group of carbides, by means of optical microscopy. MC carbides are not etched and appear in pink in the matrix; $\mathrm{M}_{2} \mathrm{C}$ in dark brown and $\mathrm{M}_{7} \mathrm{C}_{3}-\mathrm{M}_{6} \mathrm{C}$ in blue or yellow. Both $\mathrm{M}_{6} \mathrm{C}$ and $\mathrm{M}_{7} \mathrm{C}_{3}$, which are always associated and have the same colour, have to be considered as a whole when using optical microscopy.

\subsection{Image Processing}

First, carbides and matrix are separated by a simple thresholding. Because the etching is not totally reproducible from one sample to another and sometimes heterogeneous on the sample surfaces, the operator for every image chooses threshold levels interactively. Secondly, isolated MC carbides are easily extracted thanks to their average gray level. After these two first operations, unclassified pixels are $\mathrm{MC}, \mathrm{M}_{23} \mathrm{C}_{6}$ and $\mathrm{M}_{7} \mathrm{C}_{3}-\mathrm{M}_{6} \mathrm{C}$ carbides belonging to clusters.

Pixels are finally assigned to one of the three carbide types ( $\mathrm{MC}, \mathrm{M}_{23} \mathrm{C}_{6}$ and $\mathrm{M}_{7} \mathrm{C}_{3}-\mathrm{M}_{6} \mathrm{C}$ ) on the basis of their gray level value and of some criteria. For example, around and inside $\mathrm{M}_{23} \mathrm{C}_{6}-\mathrm{M}_{7} \mathrm{C}_{3}-\mathrm{M}_{6} \mathrm{C}$ carbides, matrix is digitized by pixels with gray level values equal to those of the MC because they are a transition between a bright matrix and darker carbides. So, one criterion is to assign these pixels to the matrix. Three binary images of every kind of carbides are finally obtained. Any combination of these images can be considered, like image of all carbides.

\section{Results and Discussions}

The alloys presented in Table 3 correspond to the classical HSS 6-5-2 (AISI M2) and to some of their siliconalloyed variant.

\subsection{Temperature-Concentration Sections}

High-speed tool steels are complex, multi-component alloy systems in which microstructures are very dependent on the kinetics of solidification and solid-state reactions and the non-uniform distributions of phases that accom-

Table 2. General characterization of carbides in investigated high speed tool steel.

\begin{tabular}{|c|c|c|c|c|}
\hline Types of carbides & Composition (EDX mapping) & Shape (Distribution) & $\begin{array}{c}\text { Contrast with } \\
\text { secondary } \mathrm{e}^{-}(\mathrm{SEM})\end{array}$ & $\begin{array}{c}\text { Color towards } \\
\text { Groesbeck's reagent (OM) }\end{array}$ \\
\hline $\mathrm{MC}$ & $\begin{array}{l}\mathrm{V} \text { (most present } \\
\text { element) Mo, W, Cr }\end{array}$ & $\begin{array}{c}\text { Bulky lobules or } \\
\text { Aggregates "coral-like" }\end{array}$ & Dark to dark gray & Light pink \\
\hline $\mathrm{M}_{2} \mathrm{C}$ & $\begin{array}{c}\text { Mo, W (most present elements) } \\
\text { V, Cr }\end{array}$ & $\begin{array}{c}\text { Acicular (herringbone-like) } \\
\text { Or Lamellae }\end{array}$ & White to light gray & Dark brown \\
\hline $\mathrm{M}_{7} \mathrm{C}_{3}$ & $\begin{array}{c}\mathrm{Cr} \text { (most present element) } \mathrm{V}, \\
\text { Mo Fe (slight traces) }\end{array}$ & "Fishbone-like" or lamellae & Gray & Yellow \\
\hline $\mathrm{M}_{6} \mathrm{C}$ & Mo, W (most present elements) V & $\begin{array}{c}\text { "Fishbone-like" } \\
\text { (with lamellas more tiny } \\
\text { than those in } \mathrm{M}_{7} \mathrm{C}_{3} \text { ) }\end{array}$ & White & Blue \\
\hline $\mathrm{M}_{23} \mathrm{C}_{6}$ & $\begin{array}{c}\mathrm{Cr} \text { (most present element) } \mathrm{V}, \\
\text { Mo, Fe (slight traces) }\end{array}$ & Lamellae & Gray & Attack \\
\hline
\end{tabular}

Table 3. Chemical composition of the investigated steels (wt \%).

\begin{tabular}{|c|c|c|c|c|c|c|}
\hline \multirow{2}{*}{ Steel No. } & \multicolumn{6}{|c|}{ Chemical composition, wt $\%$} \\
\hline & $\mathrm{C}$ & $\mathrm{Si}$ & $\mathrm{Cr}$ & Mo & V & W \\
\hline AISI M2 & $\begin{array}{l}1.15 \\
0.78\end{array}$ & $\begin{array}{l}0.15 \\
0.45\end{array}$ & $\begin{array}{c}3.75 \\
4.5\end{array}$ & $\begin{array}{l}3.6 \\
5.5\end{array}$ & 1.75 & $\begin{array}{l}5.5 \\
6.5\end{array}$ \\
\hline AISI M2-Si1 & 0.98 & 1.10 & 4.30 & 5.30 & 1.71 & 6.35 \\
\hline AISI M2-Si2 & 0.97 & 2.98 & 4.21 & 5.45 & 1.73 & 6.45 \\
\hline AISI M2-Si3 & 0.95 & 4.95 & 4.26 & 5.29 & 1.74 & 6.48 \\
\hline
\end{tabular}


pany these reactions. Following Hoyle [12], the best way to rationalize the microstructural changes that occur during the processing of high-speed tool steels is to consider vertical sections through the multi-component systems that make up these steels. The vertical sections plot regions of phase stability as a function of temperature and carbon content but do not give the compositions of the coexisting phases or the configuration of the phases. Nevertheless, the vertical sections indicate when various phases must form during processing, and this information together with other observations provides a good understanding of the evolution of microstructure in high-speed steels.

Four of the TC sections calculated in this work-corresponding to the alloy 6-5-2 and its three silicon variants

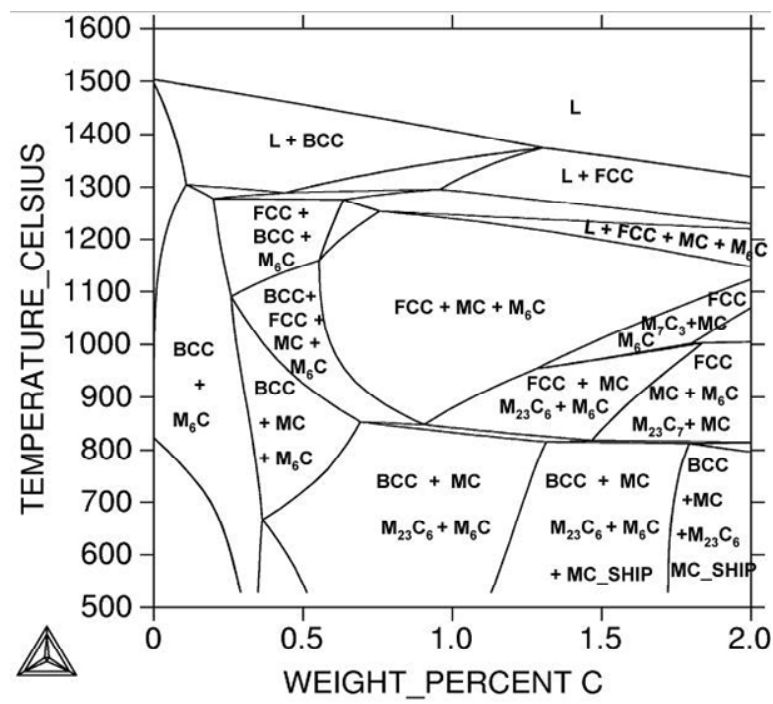

(a)

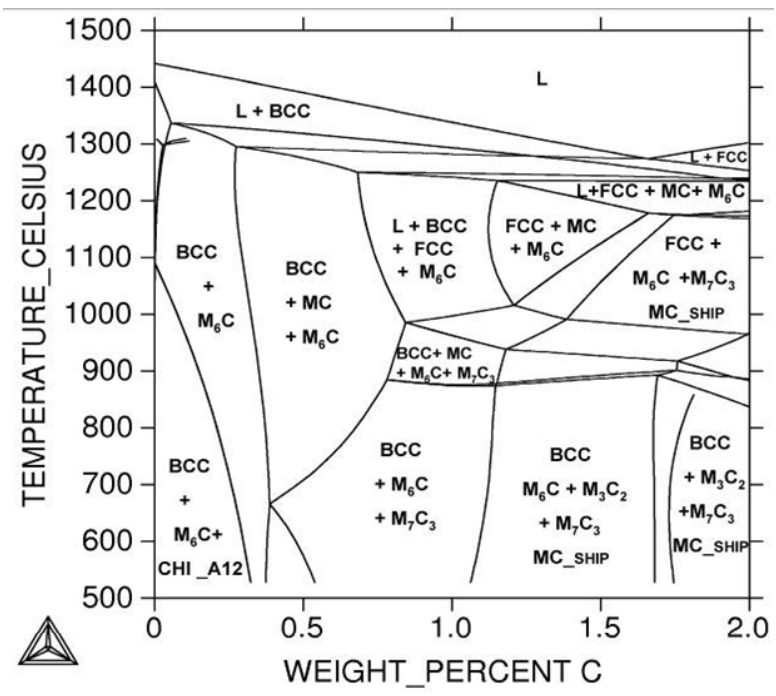

(c)
6-5-2-1, 6-5-2-3 and 6-5-2-5 (Table 2) - are shown in Figure 1. They illustrate the influence of the carbon and silicon content on the stability of the phases. The left corner of each section represents an alloy of $\mathrm{Fe}$ and $\mathrm{Cr}$ with $\mathrm{W}, \mathrm{Mo}, \mathrm{V}$, and $\mathrm{Si}$ in the ratio as they are in the basis alloy (6:5:2:0; 6:5:2:1, 6:5:2:3 and 6:5:2:5, respectively), and this ratio is kept constant while the $\mathrm{C}$ content increases to the right. The tie-lines are not in the section plane and, therefore, the amount and composition of the phases must be calculated separately. The CALPHAD method has been successfully used for computation of phase equilibrium the multi-component high speed tool steel system $[9,10,13]$. Calculated multi-component phase diagrams and property diagrams for steels are as accurate as a measured diagram, and much faster to obtain.

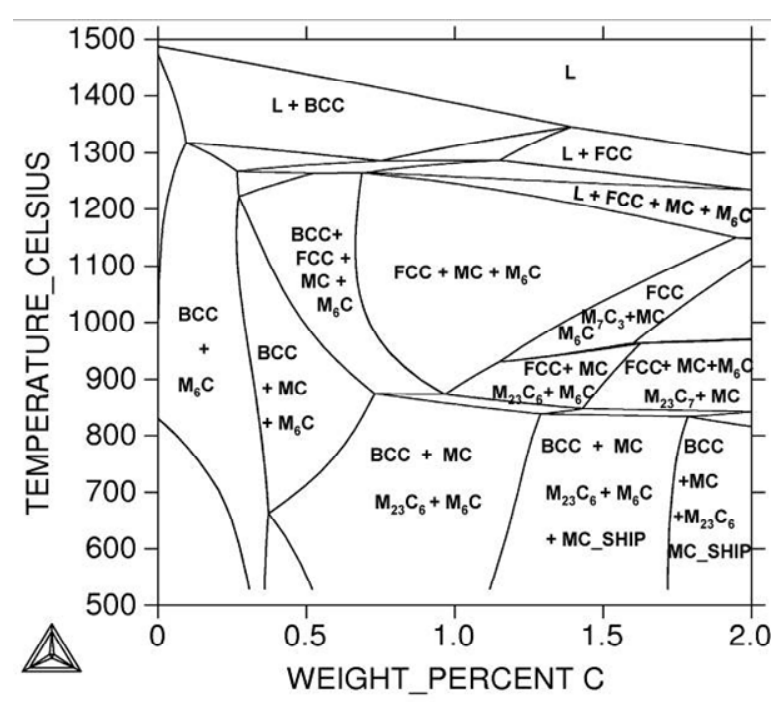

(b)

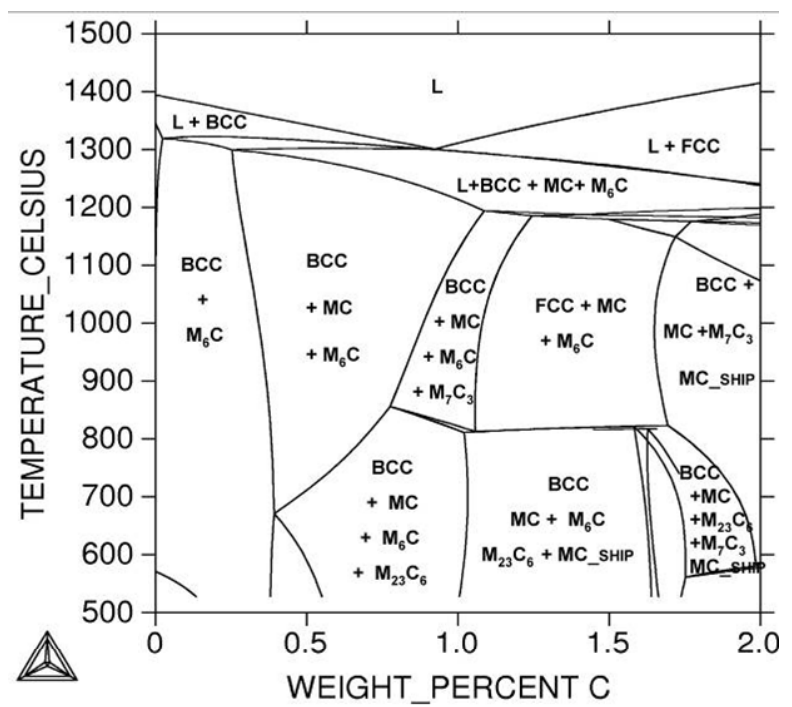

(d)

Figure 1. (a) through (d) temperature-concentration (TC) sections for standard HSS, AISI M2 and its silicon variants. (a) Standard M2; (b) $1 \% \mathrm{Si}$; (c) $3 \% \mathrm{Si}$; (d) $5 \% \mathrm{Si}$. 
The diagrams calculated below are for the tool steel with $\mathrm{Fe}-\mathrm{Cr}-\mathrm{W}-\mathrm{Mo}-\mathrm{Si}-\mathrm{V}-\mathrm{C}$. Figure 1 is an isopleth phase diagram with fixed alloy content except $\mathrm{C}$ and Fe, Figure 2 is a phase fraction diagram for a the same alloy with fixed carbon content. In Figure 1, one can recognize the usual phase fields that a high-speed steel alloy passes through as it is cooled from the liquid state. The solidification sequence of the investigated steels is complex and involves several reactions between the solid and the liquid phases, which may lead to particular microstructural characteristics, depending on the exact composition of the alloy and on the cooling rate. Because the isopleths phases diagrams for investigated steels show equilibrium phase relations, kinetic segregation effects and their consequences such as the formation of $\mathrm{M}_{2} \mathrm{C}$ are not predicted

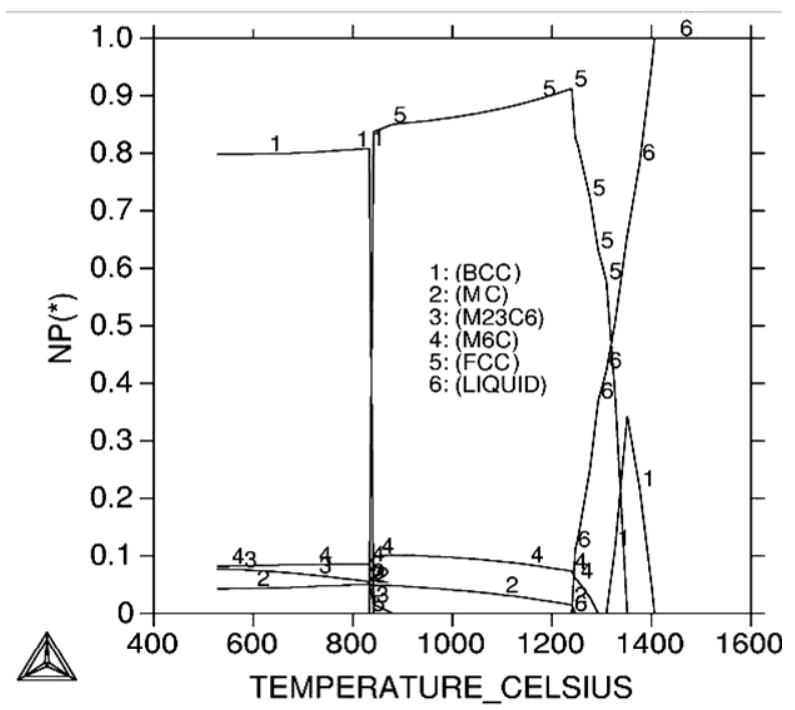

(a)

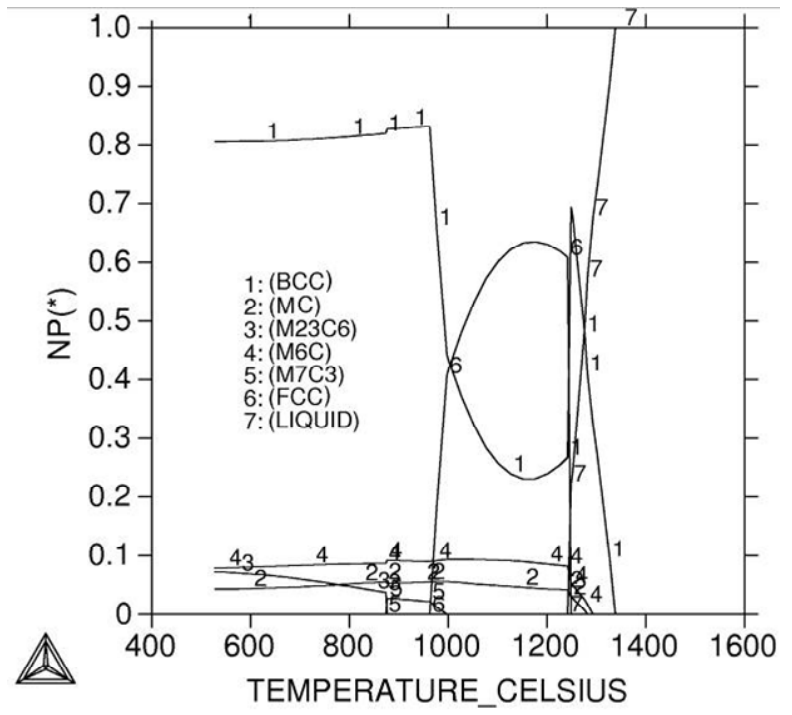

(c) by them.

\subsection{Solidification Reactions of Silicon Containing AISI M2 High Speed Tool Steel}

\subsubsection{For Standard High Speed Tool Steel, AISI M2}

In general, in Figure 3(a) at the beginning of the cooling stage the delta-ferrite solidifies first from the melt in the form of primary dendrites, according to the reaction (1), beginning at around $1435^{\circ} \mathrm{C}$.

$$
\mathrm{L} \rightarrow \text { delta - ferrite }
$$

As the separation of delta ferrite proceeds, the carbon content increases in the melt; solidification continues as a peritectic reaction. Transformation delta ferrite to austen-

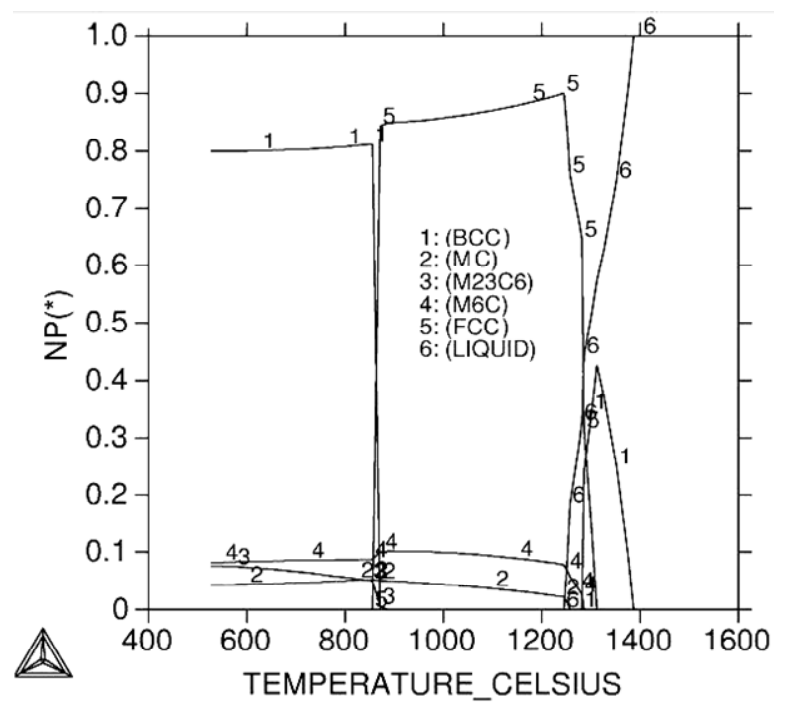

(b)

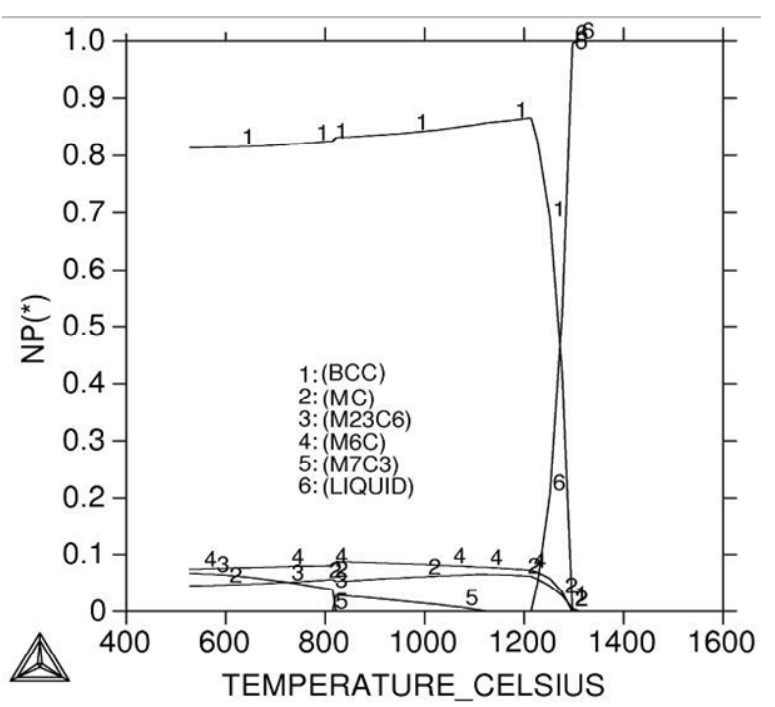

(d)

Figure 2. Temperature dependence of the amounts of phases for standard HSS, AISI M2 and its silicon variants. See Table 1 for details. (a) Standard M2; (b) $1 \% \mathrm{Si}$; (c) $3 \% \mathrm{Si}$; (d) $5 \% \mathrm{Si}$. 


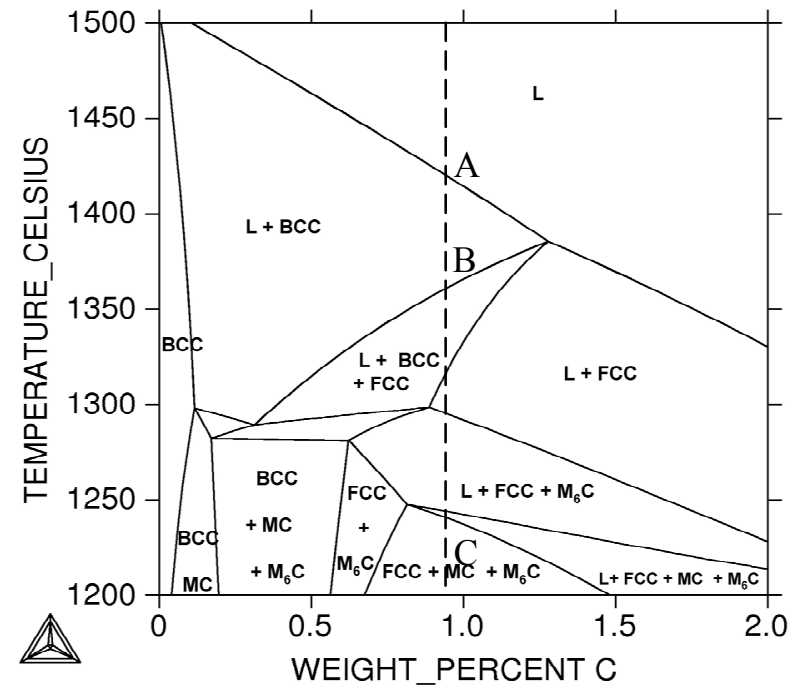

(a)

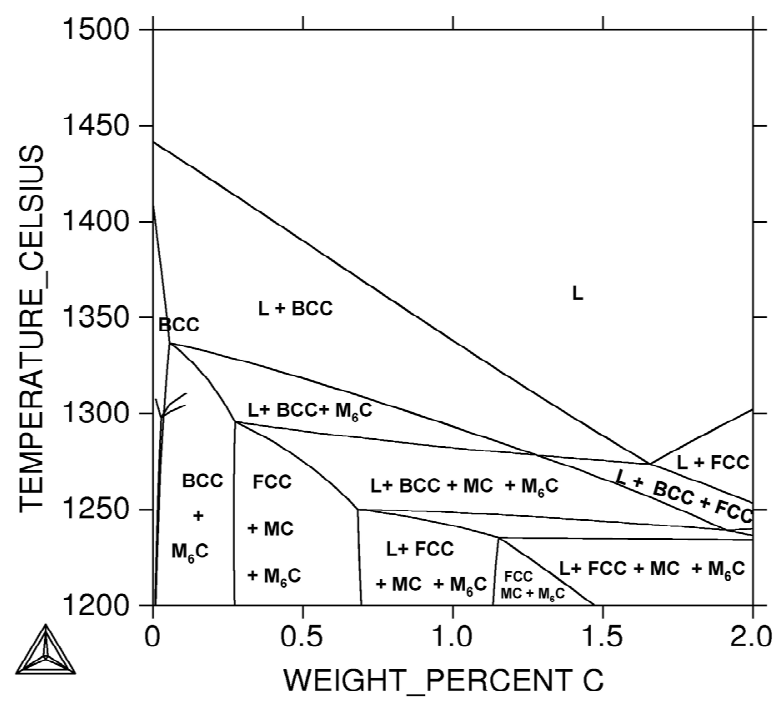

(c)

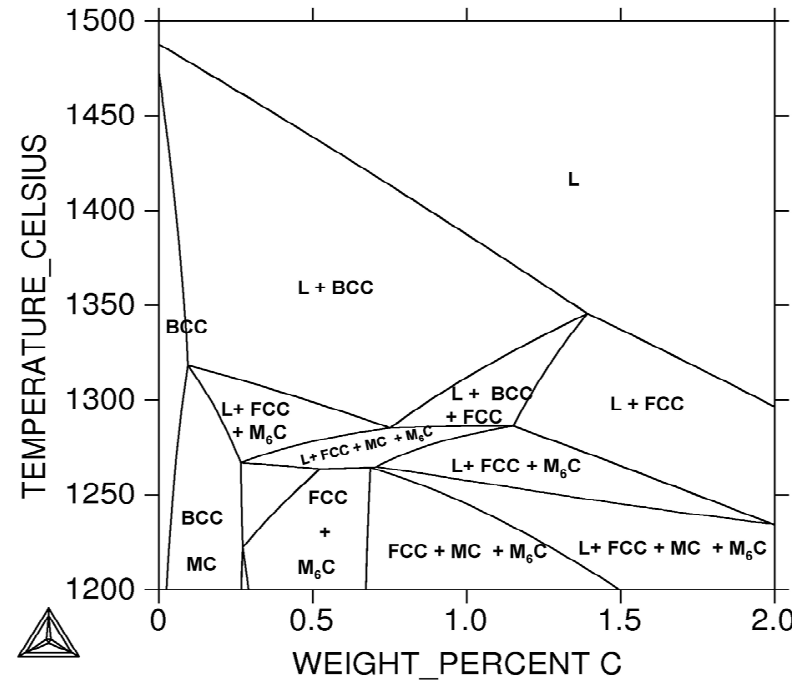

(b)

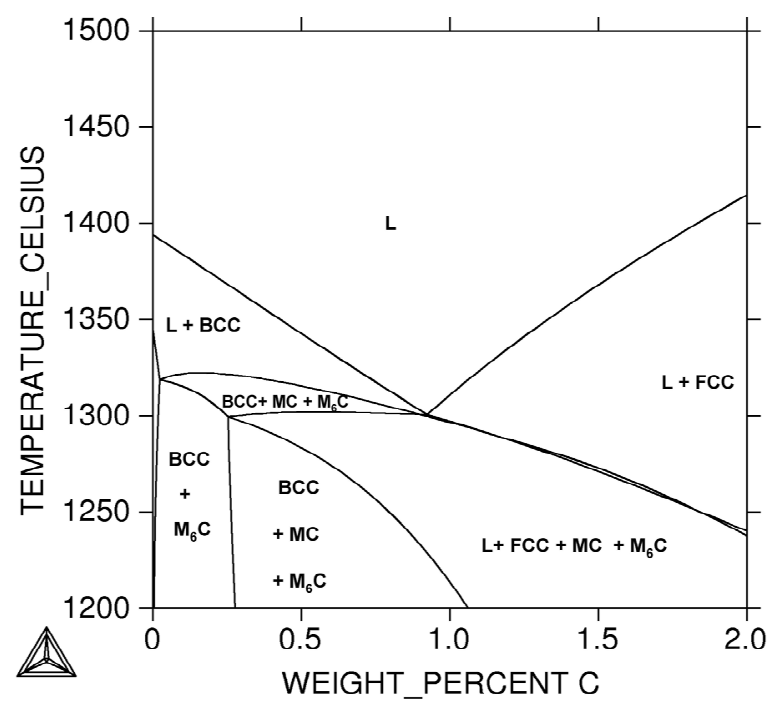

(d)

Figure 3. Magnification of the transformation zone in Figure 1. (a) Standard M2; (b) 1\% Si; (c) 3\% Si; (d) $5 \%$ Si.

ite, according to:

$$
\mathrm{L}+\text { delta ferrite } \rightarrow \text { gamma austenite }+\mathrm{L}
$$

When the liquid is leaving point $\mathrm{B}$, ferrite should normally be completely transformed. Then the un-solidified melt follows the eutectic reaction, producing austenite plus carbides, as shown in Equation (3).

$$
\mathrm{L}+\text { gamma austenite } \rightarrow \mathrm{L}+\text { gamma austenite }+\mathrm{M}_{6} \mathrm{C} \text { (3) }
$$

As we mentioned previously, two kinds of carbide are present in the eutectic. Globular carbides, identified as $\mathrm{M}_{6} \mathrm{C}$ carbides, are grown in the interdendritic eutectic in contact with the austenite dendrites, as it may be anticipated from reaction (3).

The MC carbides nucleate on them and grow in a further stage closing the solidification sequence at point $\mathrm{C}$ by the eutectic decomposition of the last remaining liquid. As a matter of fact, the morphology of the $\mathrm{M}_{6} \mathrm{C}$ particles and their location suggests that they have solidified before MC. The above observations stating that the $\mathrm{M}_{6} \mathrm{C}$ solidifies before MC. In our work, we can state that, the $\mathrm{MC}$ solidifies from the residual liquid at around $1230^{\circ} \mathrm{C}$. However the $\mathrm{MC}$ carbides predominate in the eutectic and their formation in expense of the $\mathrm{M}_{6} \mathrm{C}$ carbides is justified, because $\mathrm{MC}$ is favored from a relatively high carbon and vanadium content in the melt.

\subsubsection{For Silicon Content (1\% Si)}

Figure 3(b) shows that, for silicon containing high speed tool steel reaction (3) may be changed due to effect of silicon on transformation temperature to the following reactions in sequence: 


$$
\begin{aligned}
& \mathrm{L}+\text { delta ferrite + gamma austenite } \rightarrow \\
& \mathrm{L}+\text { delta ferrite + gamma austenite }+\mathrm{M}_{6} \mathrm{C}
\end{aligned}
$$

It well known that, silicon is one of strong ferrite stabilizer element and the presence of silicon leads to precipitate $\mathrm{M}_{6} \mathrm{C}$ instead of $\mathrm{MC}$ in silicon free high speed steel. We can reported that, $\mathrm{M}_{6} \mathrm{C}$ carbide precipitate first at the grain boundary of austenite which deplete the carbon and increase the alloying elements in the adjacent liquid. From the previous, precipitation of MC carbide was precipitate according to the following reaction:

$$
\begin{aligned}
& \mathrm{L}+\text { gamma austenite }+\mathrm{M}_{6} \mathrm{C} \rightarrow \\
& \mathrm{L}+\text { gamma austenite }+\mathrm{M}_{6} \mathrm{C}+\mathrm{MC}
\end{aligned}
$$

By continues cooling of the investigated steels the reaction leads to increase the size and volume of the $\mathrm{MC}$ carbides.

$$
\begin{aligned}
& \mathrm{L}+\text { gamma austenite }+\mathrm{M}_{6} \mathrm{C}+\mathrm{MC} \rightarrow \\
& \text { gamma austenite }+\mathrm{M}_{6} \mathrm{C}+\mathrm{MC}
\end{aligned}
$$

We can concluded that silicon containing high speed tool steel after solidification include austenite with two different kind of carbides $\left(\mathrm{MC}+\mathrm{M}_{6} \mathrm{C}\right)$.

\subsubsection{For Higher Silicon Content ( $3 \% \mathrm{Si}$ )}

For higher silicon content $(3 \% \mathrm{Si})$, as we mentioned before with increasing the silicon content leads to $\mathrm{M}_{6} \mathrm{C}$ carbide precipitate from the liquid but the rest is same, as shown in Figure 3(c). $\mathrm{M}_{6} \mathrm{C}$ carbides pins the austenite grains to grow then the structure is very fine at the solidification end. During solidification process, different carbides with different chemical composition were precipitated above the $\mathrm{M}_{6} \mathrm{C}$ carbides. So, we can expect that the precipitated carbide grow very much and the chemical

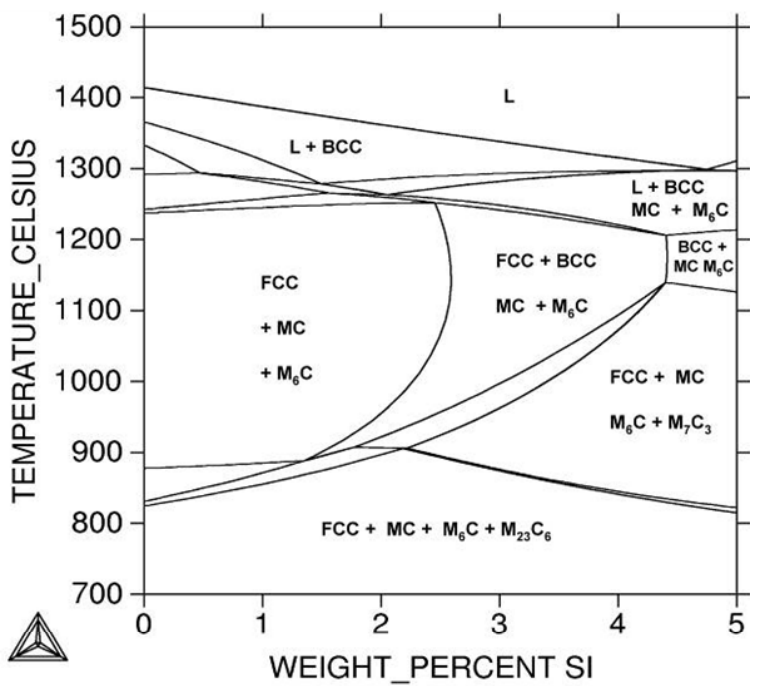

(a) composition changes along the carbide.

\subsubsection{The Effect of Higher Silicon}

The effect of higher silicon contents can be understood with the help of Figure 3(d), where a TC section based on an alloy with 5 mass pct $\mathrm{Si}$ is depicted. It can be seen that MC should be the first phase to solidify, directly from the liquid, preceding the crystallization of delta ferrite. This was taken to indicate that the MC had begun to crystallize long before the delta ferrite, giving it enough time to grow in the liquid without disturbance.

With higher carbon content, the solidification path tends to change from primary formation of delta ferrite to austenite, and the liquidus temperature decreases, in agreement with the literature [14-16]. Actually, Figure 3(a) shows that increased carbon content had three obvious effects on the AISI M2 concentration-temperature diagram. It depressed the liquidus and solidus but raised the peritectic, thus narrowing and eventually eliminating the gap between the liquidus and the peritectic at high carbon contents which caused primary crystallization of austenite at $>1.38$ wt pet $\mathrm{C}$ for standard AISI M2 $(0.4 \% \mathrm{Si})$ but this critical value of carbon was effected by the additions of silicon, Figure 3.

A better view of the influence of silicon on investigated steels is provided in Figure 4, where TC section is shown together with an enlargement of Figure 3(b). The addition of silicon to M2 steel promotes ferrite formation instead of the austenite-stabilizing effect of carbon. Analysis of Figure 4 shows that the liquidus and solidus temperatures were only slightly affected by small or moderate increases in the nominal silicon content, but the peritectic was strongly depressed. This widens the gap between the liquidus and the peritectic, since the crystal-

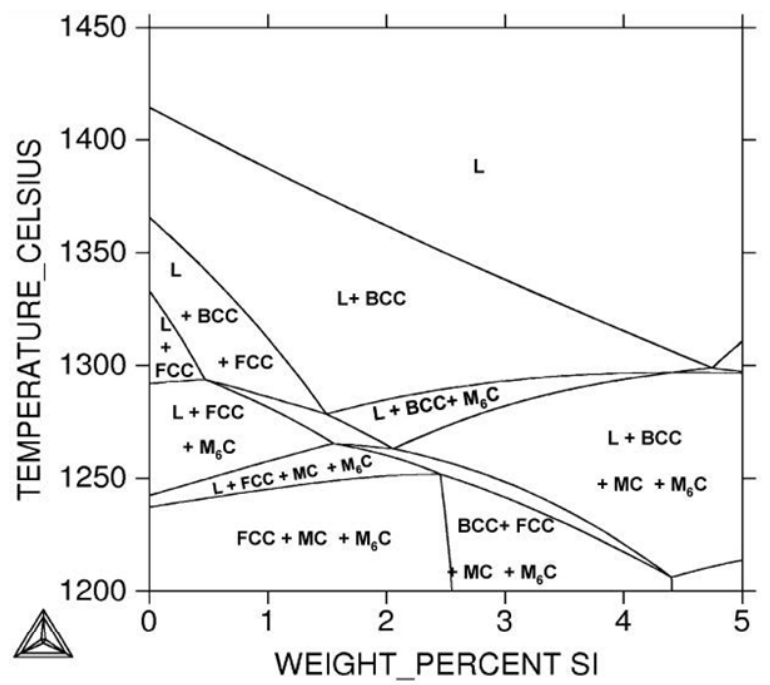

(b)

Figure 4. (a) Temperature-concentration (TC) section based on chemical composition of AISI M2 steel. (b) Magnification of the transformation zone in (a). 
lization of a greater volume fraction of ferrite is now required before the remaining melt becomes sufficiently enriched in carbon to trigger the austenite reaction. On the other hand, increase silicon contents cause a strong stabilization of the $\mathrm{M}_{6} \mathrm{C}$ carbide. Already at low silicon concentrations, the $\mathrm{M}_{6} \mathrm{C}$-eutectic transformation occurs at a higher temperature than that of the MC.

\subsection{Transformation Temperatures and Amounts of Phases}

Many DTA measurements have been reported for HSS 6-5-2 [17] with which we can compare the results of the calculations. Unfortunately, because of kinetic effects accompanying solidification, not all of them can be associated with a transformation that would occur in equilibrium. For example, segregation and incomplete peritectic reactions lead to different transformation sequences and thus to different transformation temperatures. Usually, measurements of the liquidus temperatures are the most reliable ones, but they are not always available. Also usually not available are solid-state reaction temperatures, such as the alpha-ferrite to austenite transformation, which could serve for comparisons in the low-temperature region. Table 4 shows the measured liquidus and solidus temperatures together with the calculated values for the investigated steels listed in Table 3 . The calculated values are consistently in good agreement with the meas- urements of Reference [17]. The calculated and measured amounts of phases for a Si-containing HSS 6-5-2 alloy are given in Table 5. A good agreement is also observed here.

\subsection{Composition of the Carbides and Matrix}

It well known that, the microstructures in as-cast highspeed steels may take several morphologies and consist of various alloy carbides, depending on steel composition and solidification conditions. The primary alloy carbide in high-speed steels is $\mathrm{M}_{6} \mathrm{C}$, where $\mathrm{M}$, the metal component, may consist of tungsten, molybdenum, and iron. Vanadium is typically present in $\mathrm{MC}$ carbides, and tungsten and molybdenum may be present in $\mathrm{M}_{2} \mathrm{C}$ carbides.

Figure 5 shows, as an example, the variation of composition with temperature for the carbide $\mathrm{M}_{6} \mathrm{C}$ in the alloy 6-5-2-1 Si. According to the calculations, this carbide should crystallize at $1286^{\circ} \mathrm{C}$, and should continue in contact with the melt down to $1246^{\circ} \mathrm{C}$. Below this, only solid phases should be found. Since the austenitization treatment of this steel is performed at about $1230^{\circ} \mathrm{C}$, it should produce a state close to the thermodynamic equilibrium. Therefore, the compositions of the carbides after austenitization (and quenching and tempering, which causes no further changes in the blocky carbides) may be used here as a legitimate basis for comparison. The calculated phase compositions and the measured values are presented

Table 4. Calculated and measured liquidus and solidus temperature at the AISI M2 and its three silicon variants.

\begin{tabular}{cccccc}
\hline \multirow{2}{*}{ Alloy } & Designation & \multicolumn{2}{c}{ Calculated } & \multicolumn{2}{c}{ Measured } \\
\cline { 3 - 6 } & & Solidus & Liquidus & Solidus & Liquidus \\
\hline AISI M2-LC & $6-5-2-\mathrm{LC}$ & 1243 & 1434 & 1245 & 1433 \\
AISI M2-HC & $6-5-2-\mathrm{HC}$ & 1224 & 1399 & 1225 & 1404 \\
AISI M2-Si1 & $6-5-2-1 \% \mathrm{Si}$ & 1246 & 1343 & 1240 & 1390 \\
AISI M2-Si2 & $6-5-2-3 \% \mathrm{Si}$ & 1242 & 1315 & 1219 & 1318 \\
AISI M2-Si3 & $6-5-2-5 \% \mathrm{Si}$ & 1215 & & & 1349 \\
\hline
\end{tabular}

Table 5. Calculated and measured [18] amount of phases in an investigated high speed tool steel given in mole percent.

\begin{tabular}{|c|c|c|c|c|c|c|c|c|c|}
\hline \multirow{3}{*}{$\begin{array}{c}\text { Steel } \\
\text { Number }\end{array}$} & \multirow{3}{*}{ Designation } & \multicolumn{8}{|c|}{ Phase present volume, $\%$} \\
\hline & & \multicolumn{4}{|c|}{ Calculated } & \multicolumn{4}{|c|}{ Measured } \\
\hline & & $\mathrm{BCC}$ & $\mathrm{M}_{6} \mathrm{C}$ & $\mathrm{M}_{23} \mathrm{C}_{7}$ & $\mathrm{MC}$ & $\mathrm{BCC}$ & $\mathrm{M}_{6} \mathrm{C}$ & $\mathrm{M}_{23} \mathrm{C}_{7}$ & $\mathrm{MC}$ \\
\hline AISI M2-LC & $6-5-2-\mathrm{LC}$ & 76.50 & 7.20 & 11.00 & 5.30 & 77.00 & 7.40 & 10.50 & 5.10 \\
\hline AISI M2-HC & $6-5-2-\mathrm{HC}$ & 79.00 & 8.40 & 7.80 & 4.80 & 79.60 & 8.40 & 7.70 & 4.30 \\
\hline AISI M2-Si1 & $6-5-2-1 \% \mathrm{Si}$ & 80.00 & 8.30 & 7.30 & 4.2 & 80.10 & 8.10 & 7.20 & 4.60 \\
\hline AISI M2-Si2 & $6-5-2-3 \% \mathrm{Si}$ & 80.6 & 8.1 & 6.8 & 4.5 & 81.55 & 7.60 & 6.65 & 4.20 \\
\hline AISI M2-Si3 & $6-5-2-5 \% \mathrm{Si}$ & 81.5 & 7.5 & 6.3 & 4.7 & 81.85 & 7.50 & 6.35 & 4.30 \\
\hline
\end{tabular}


in Table 6 for the $\mathrm{M}_{6} \mathrm{C}$ carbide, in Table 7 for $\mathrm{MC}$, in Table 8 for $\mathrm{M}_{23} \mathrm{C}_{6}$ and in Table 9 for the matrix.

$\mathbf{M}_{6} \mathbf{C}$ : a tungsten- or molybdenum-rich carbide corresponding to the complex FCC carbide of the composition range $\mathrm{Fe}_{3} \mathrm{~W}_{3} \mathrm{C}$ to $\mathrm{Fe}_{4} \mathrm{~W}_{2} \mathrm{C}$ in tungsten steels, or $\mathrm{Fe}_{3} \mathrm{Mo}_{3} \mathrm{C}$ to $\mathrm{Fe}_{4} \mathrm{Mo}_{2} \mathrm{C}$ in molybdenum steels, and capable of dissolving some chromium, vanadium, and cobalt. The obtained results show that, agreement between calculated and measured values is good for all the elements, when the experimental scatter is taken into account. From the result of Table 6, addition of silicon increase tungsten and molybdenum in the precipitated carbides. From pre- vious results we can conclude that, addition of silicon to investigated steels promotes the formation of $\mathrm{M}_{6} \mathrm{C}$ type carbides. Consonant with the measurements, silicon is not found in this carbide in any of the HSS-Si.

MC: a vanadium-rich carbide corresponding to the FCC carbide of composition range $\mathrm{VC}$ to $\mathrm{V}_{4} \mathrm{C}_{3}$ and capable of dissolving limited amounts of tungsten, molybdenum, chromium, and iron. Table 7 shows that introduction of silicon to investigated steels leads to increase content of dissolving elements in such carbides for example $\mathrm{Cr}, \mathrm{Mo}, \mathrm{W}$ and Fe. In addition, Table 7 shows that the precipitate carbide contains lower carbon content than

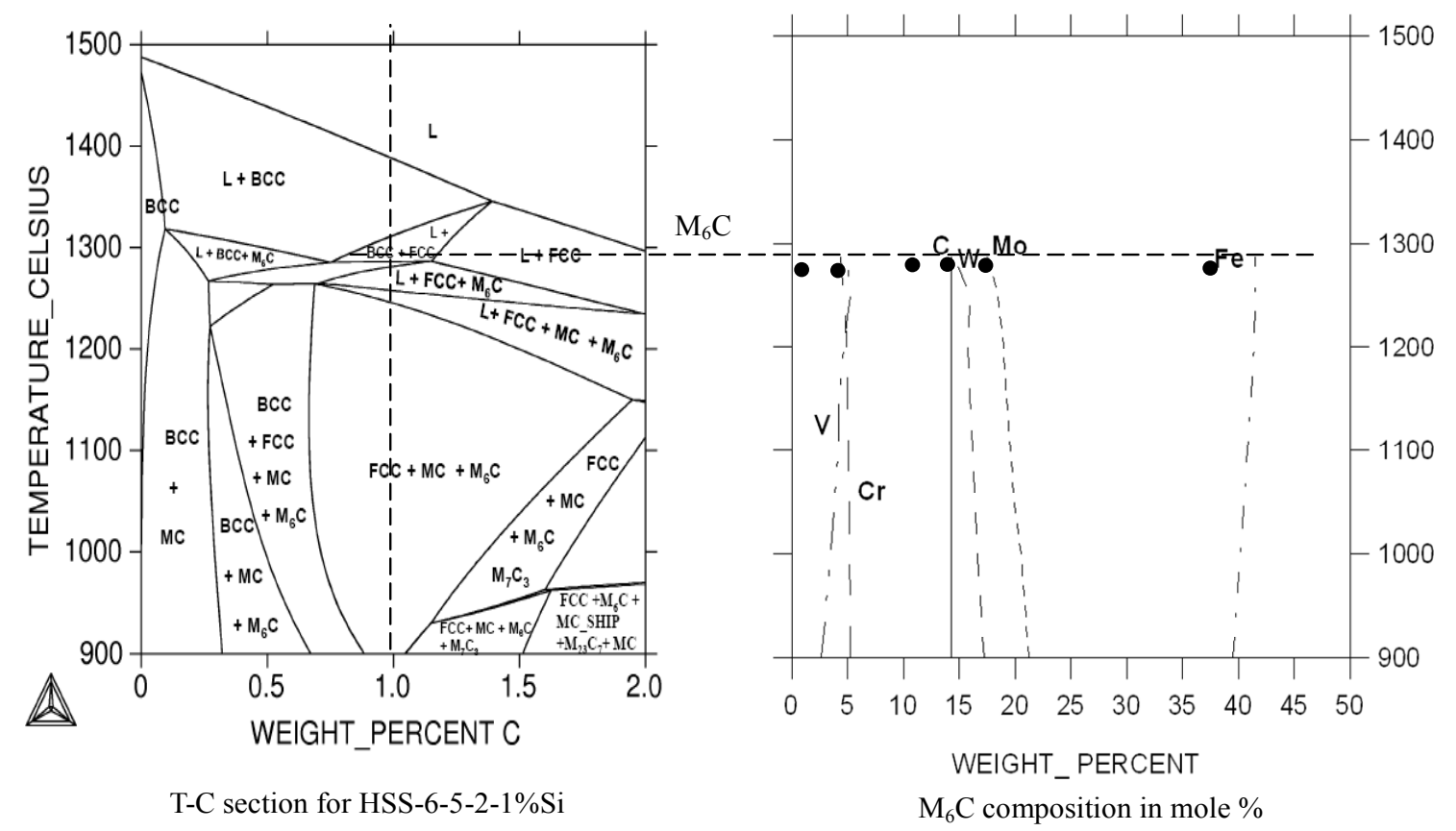

Figure 5. Calculated and measured [16] $\mathrm{M}_{6} \mathrm{C}$ composition in alloy 6-5-2-1 Si.

Table 6. Calculate and measured composition of the $\mathrm{M}_{6} \mathrm{C}$ carbides.

\begin{tabular}{|c|c|c|c|c|c|c|c|c|c|}
\hline \multirow{2}{*}{ Alloy } & \multirow{2}{*}{ Designation } & \multirow{2}{*}{ State } & \multicolumn{7}{|c|}{ Chemical Composition, mole $\%$} \\
\hline & & & $\mathrm{C}$ & $\mathrm{Si}$ & $\mathrm{Cr}$ & Mo & $\mathrm{V}$ & $\mathrm{W}$ & $\mathrm{Fe}$ \\
\hline \multirow{2}{*}{ AISI M2-LC } & \multirow{2}{*}{ 6-5-2-LC } & Calculated & 14.3 & - & 2.85 & 21.1 & 2.93 & 20.8 & 38 \\
\hline & & Measured & 14.2 & - & 4.8 & 20.1 & 3.5 & 14.1 & 43.3 \\
\hline \multirow{2}{*}{ AISI M2-HC } & \multirow{2}{*}{$6-5-2-\mathrm{HC}$} & Calculated & 14.3 & - & 2.18 & 19.3 & 1.59 & 22.52 & 40.11 \\
\hline & & Measured & 14.3 & - & 5.1 & 21.3 & 3.7 & 13.9 & 41.7 \\
\hline \multirow{2}{*}{ AISI M2-Si1 } & \multirow{2}{*}{$6-5-2-1 \% \mathrm{Si}$} & Calculated & 2.03 & - & 1.79 & 24.36 & 1.74 & 45.2 & 24.92 \\
\hline & & Measured & 1.4 & - & 3.42 & 26.10 & 3.73 & 39.7 & 25.65 \\
\hline \multirow{2}{*}{ AISI M2-Si2 } & \multirow{2}{*}{$6-5-2-3 \% \mathrm{Si}$} & Calculated & 2.01 & - & 1.86 & 24.94 & 1.61 & 45.33 & 24.23 \\
\hline & & Measured & 1.56 & - & 4.20 & 27.6 & 2.97 & 38.5 & 25.17 \\
\hline \multirow{2}{*}{ AISI M2-Si3 } & \multirow{2}{*}{$6-5-2-5 \% \mathrm{Si}$} & Calculated & 1.99 & - & 1.89 & 25.46 & 1.38 & 46.15 & 23.12 \\
\hline & & Measured & 1.91 & - & 4.35 & 25.03 & 2.63 & 40.1 & 25.98 \\
\hline
\end{tabular}


Table 7. Calculate and measured composition of the MC carbides.

\begin{tabular}{|c|c|c|c|c|c|c|c|c|c|}
\hline \multirow{2}{*}{ Alloy } & \multirow{2}{*}{ Designation } & \multirow{2}{*}{ State } & \multicolumn{7}{|c|}{ Chemical Composition, mole $\%$} \\
\hline & & & $\mathrm{C}$ & $\mathrm{Si}$ & $\mathrm{Cr}$ & Mo & $\mathrm{V}$ & W & $\mathrm{Fe}$ \\
\hline \multirow{2}{*}{ AISI M2-LC } & \multirow{2}{*}{ 6-5-2-LC } & Calculated & 46.35 & - & 1.49 & 8.64 & 41.14 & 2.32 & 0.417 \\
\hline & & Measured & & & 2.6 & 6.4 & 36.2 & 4.9 & 4.9 \\
\hline \multirow{2}{*}{ AISI M2-HC } & \multirow{2}{*}{$6-5-2-\mathrm{HC}$} & Calculated & 46.78 & - & 1.45 & 10.65 & 37.62 & 3.44 & 0.564 \\
\hline & & Measured & & & 4 & 7.1 & 28.8 & 3.00 & 4.2 \\
\hline \multirow{2}{*}{ AISI M2-Si1 } & \multirow{2}{*}{$6-5-2-1 \% \mathrm{Si}$} & Calculated & 13.9 & - & 1.97 & 21.07 & 52 & 10.97 & 0.567 \\
\hline & & Measured & 13.95 & & 3.61 & 19.90 & 48.64 & 8.56 & 5.34 \\
\hline \multirow{2}{*}{ AISI M2-Si2 } & \multirow{2}{*}{$6-5-2-3 \% \mathrm{Si}$} & Calculated & 13.6 & - & 2.03 & 21.99 & 49.90 & 12.39 & 0.51 \\
\hline & & Measured & 12.65 & & 3.95 & 21.05 & 43.65 & 11.95 & 6.75 \\
\hline \multirow{2}{*}{ AISI M2-Si3 } & \multirow{2}{*}{$6-5-2-5 \% \mathrm{Si}$} & Calculated & 13.15 & - & 2.055 & 23.35 & 46.02 & 15.28 & 0.435 \\
\hline & & Measured & 10.24 & & 4.01 & 22.95 & 42.19 & 13.29 & 7.32 \\
\hline
\end{tabular}

Table 8. Calculate and measured composition of the $\mathrm{M}_{23} \mathrm{C}_{6}$ carbides.

\begin{tabular}{|c|c|c|c|c|c|c|c|c|c|}
\hline \multirow{2}{*}{ Alloy } & \multirow{2}{*}{ Designation } & \multirow{2}{*}{ State } & \multicolumn{7}{|c|}{ Chemical Composition, mole \% } \\
\hline & & & $\mathrm{C}$ & $\mathrm{Si}$ & $\mathrm{Cr}$ & Mo & $\mathrm{V}$ & $\mathrm{W}$ & $\mathrm{Fe}$ \\
\hline \multirow{2}{*}{ AISI M2-LC } & \multirow{2}{*}{ 6-5-2-LC } & Calculated & 20.69 & - & 35.35 & 7.85 & 0.29 & 1.02 & 35 \\
\hline & & Measured & 20.00 & & 34.97 & 7.75 & 0.27 & 1.00 & 36 \\
\hline \multirow{2}{*}{ AISI M2-HC } & \multirow{2}{*}{$6-5-2-\mathrm{HC}$} & Calculated & 20.69 & - & 26.77 & 7.45 & 0.18 & 1.22 & 43.87 \\
\hline & & Measured & 20.82 & & 26.70 & 7.51 & 0.20 & 1.20 & 43.57 \\
\hline \multirow{2}{*}{ AISI M2-Si1 } & \multirow{2}{*}{$6-5-2-1 \% \mathrm{Si}$} & Calculated & 4.98 & - & 38.1 & 15.31 & 0.28 & 3.67 & 37.89 \\
\hline & & Measured & 4.97 & & 38.5 & 15.27 & 0.26 & 3.79 & 37.21 \\
\hline \multirow{2}{*}{ AISI M2-Si2 } & \multirow{2}{*}{$6-5-2-3 \% \mathrm{Si}$} & Calculated & 4.99 & - & 42.15 & 15.91 & 0.23 & 3.48 & 33.46 \\
\hline & & Measured & 5.03 & & 43.7 & 15.69 & 0.24 & 3.43 & 31.91 \\
\hline \multirow{2}{*}{ AISI M2-Si3 } & \multirow{2}{*}{$6-5-2-5 \% \mathrm{Si}$} & Calculated & 5.00 & - & 48.06 & 16.82 & 0.148 & 3.1 & 27 \\
\hline & & Measured & 5.09 & & 48.50 & 16.74 & 0.150 & 3.3 & 26.22 \\
\hline
\end{tabular}

Table 9. Calculate and measured composition of the matrix.

\begin{tabular}{|c|c|c|c|c|c|c|c|c|c|}
\hline \multirow{2}{*}{ Alloy } & \multirow{2}{*}{ Designation } & \multirow{2}{*}{ State } & \multicolumn{7}{|c|}{ Chemical Composition, mole $\%$} \\
\hline & & & $\mathrm{C}$ & $\mathrm{Si}$ & $\mathrm{Cr}$ & Mo & $\mathrm{V}$ & W & $\mathrm{Fe}$ \\
\hline \multirow{2}{*}{ AISI M2-LC } & \multirow{2}{*}{$6-5-2-\mathrm{LC}$} & Calculated & 0.843 & - & 3.98 & 2.09 & 1.51 & 1.33 & 90.20 \\
\hline & & Measured & 0.60 & - & 4.30 & 3.3 & 0.6 & 3.7 & 87.50 \\
\hline \multirow{2}{*}{ AISI M2-HC } & \multirow{2}{*}{$6-5-2-\mathrm{HC}$} & Calculated & 1.00 & - & 3.57 & 1.92 & 1.18 & 1.34 & 90.98 \\
\hline & & Measured & 0.650 & - & 4.30 & 4.4 & 0.8 & 4.1 & 85.75 \\
\hline \multirow{2}{*}{ AISI M2-Si1 } & \multirow{2}{*}{$6-5-2-1 \% \mathrm{Si}$} & Calculated & 0.705 & 2.99 & 3.98 & 1.71 & 1.04 & 1.06 & 88.52 \\
\hline & & Measured & 0.697 & 2.93 & 3.98 & 1.67 & 1.14 & 1.16 & 88.42 \\
\hline \multirow{2}{*}{ AISI M2-Si2 } & \multirow{2}{*}{$6-5-2-3 \% \mathrm{Si}$} & Calculated & 0.670 & 7.75 & 3.90 & 1.18 & 0.44 & 0.71 & 85.40 \\
\hline & & Measured & 0.667 & 7.85 & 3.94 & 1.14 & 0.44 & 0.71 & 85.25 \\
\hline \multirow{2}{*}{ AISI M2-Si3 } & \multirow{2}{*}{$6-5-2-5 \% \mathrm{Si}$} & Calculated & 0.751 & 11.25 & 3.87 & 0.919 & 0.20 & 0.54 & 82.47 \\
\hline & & Measured & 0.749 & 11.35 & 3.89 & 0.929 & 0.20 & 0.545 & 82.34 \\
\hline
\end{tabular}


standard AISI M2 steel.

$\mathbf{M}_{23} \mathbf{C}_{6}$ : a chromium-rich carbide corresponding to the FCC carbide $\mathrm{Cr}_{23} \mathrm{C}_{6}$ and capable of dissolving iron, tungsten, molybdenum, and vanadium. Table 8 shows that the chemical composition of calculated and measured $\mathrm{M}_{23} \mathrm{C}_{6}$ carbides. From the result of this, Table 8 increases silicon content leads to dissolve more chromium, vanadium and tungsten on comparable with standard value in high speed tool steel AISI M2. Table 8 also shows that the decrease in the carbon content of silicon containing high speed AISI M2 steels.

Matrix: The composition of the matrix is of great importance, because it determines the starting state for the precipitation of the secondary carbides [19]. Table 9 shows the calculated and measured values for some alloys. The concordance here is also good.

The matrix of the investigated steel contains the lowest content of vanadium, molybdenum and tungsten because most of this elements soluble in carbides. It well known that silicon is ferrite stabilizer and ensure the formation of carbides with high alloying content but with less carbon, Table 9.

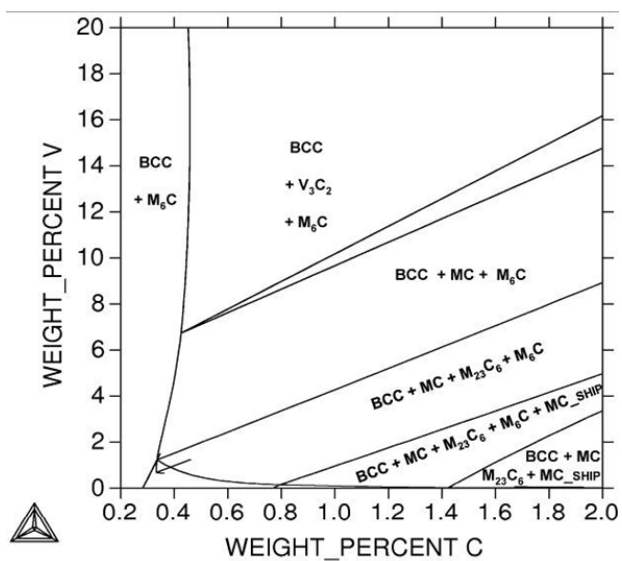

(a)

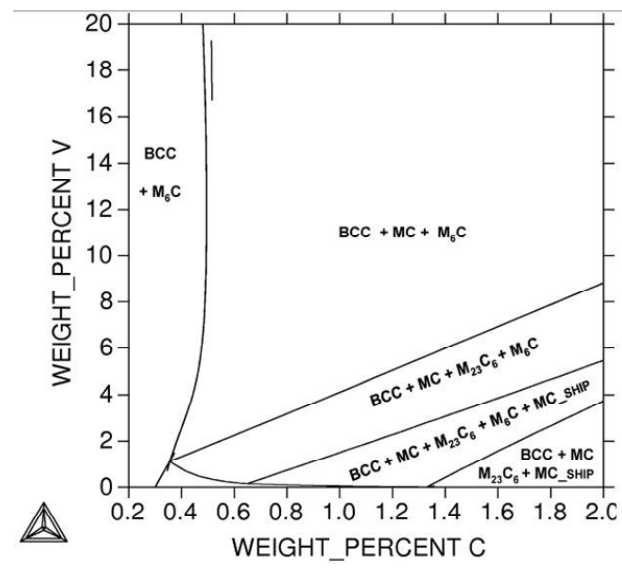

(c)
We can expect that after full heat treatment (hardening-tempering) of investigated steels, the matrix of the investigated steel will contain the highest content of vanadium, tungsten because the $\mathrm{M}_{23} \mathrm{C}_{6}$ and $\mathrm{M}_{6} \mathrm{C}$ carbides in this steel, even enriched with vanadium and tungsten is less stable during heating and more soluble in the austenite than the vanadium-base MC carbide. But to be sure about this exception it needs more work and effort.

\subsection{Effect of Alloying Elements}

The composition of the most studied and the best known high-speed steel AISI M2 has been chiefly developed about 100 years ago as a result of the determination of the cutting properties of tools produced from numerous heats in which the concentration of carbon, tungsten, chromium, molybdenum, vanadium and other alloying components was varied in narrow ranges. The steel contained about $1 \% \mathrm{C}, 6.65 \% \mathrm{~W}, 4 \% \mathrm{Cr}, 5 \% \mathrm{Mo}$ and $2 \% \mathrm{~V}$ and had a quite high hardness of up to $62 \mathrm{HRC}$.

Figure 6 presents a part of the phase diagram of alloys of the Fe-V-C system; it is shown that the introduction of

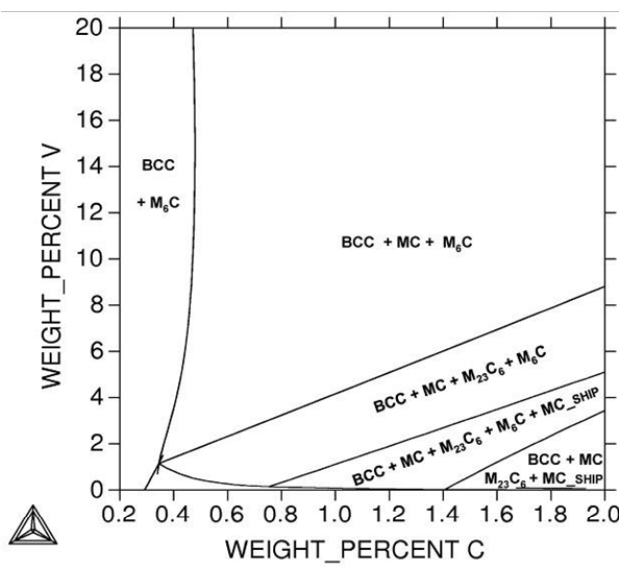

(b)

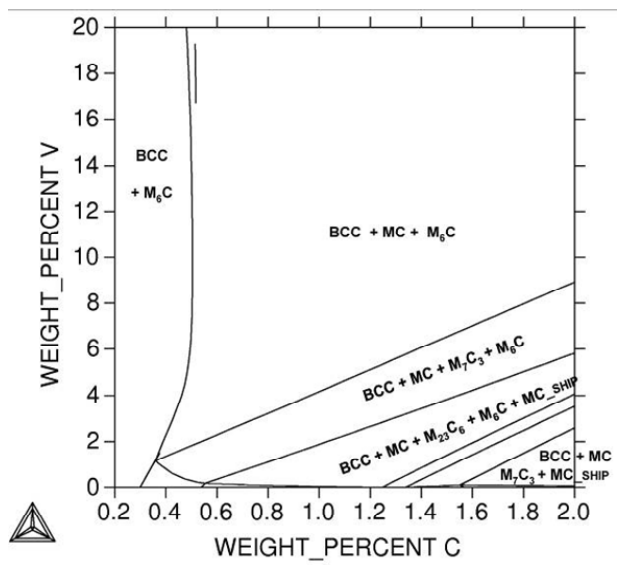

(d)

Figure 6. Portion of the $727^{\circ} \mathrm{C}\left(1000^{\circ} \mathrm{K}\right)$ isothermal section of the Fe-V-C system with compositions of investigated steels indicated. (a) Standard M2; (b) $1 \% \mathrm{Si}$; (c) $3 \% \mathrm{Si}$; (d) $5 \% \mathrm{Si}$. 


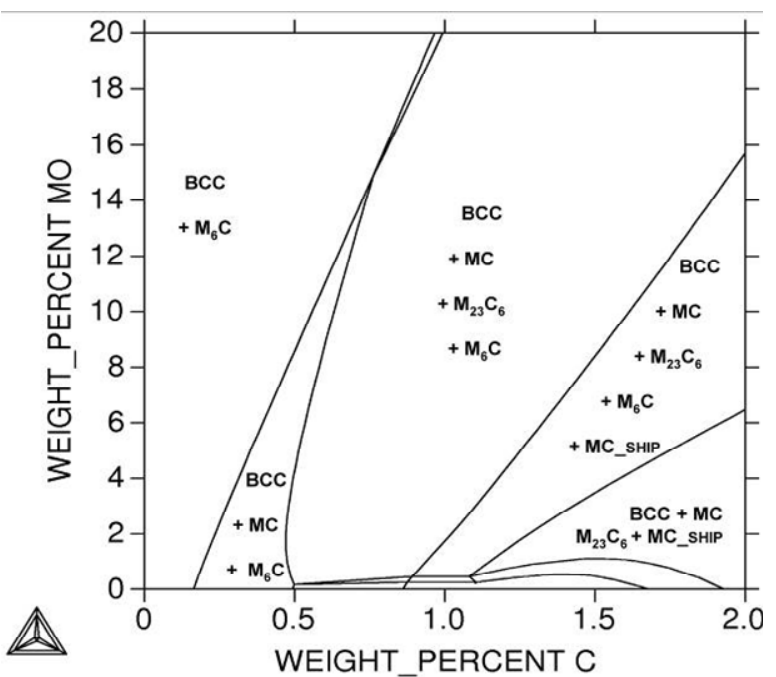

(a)

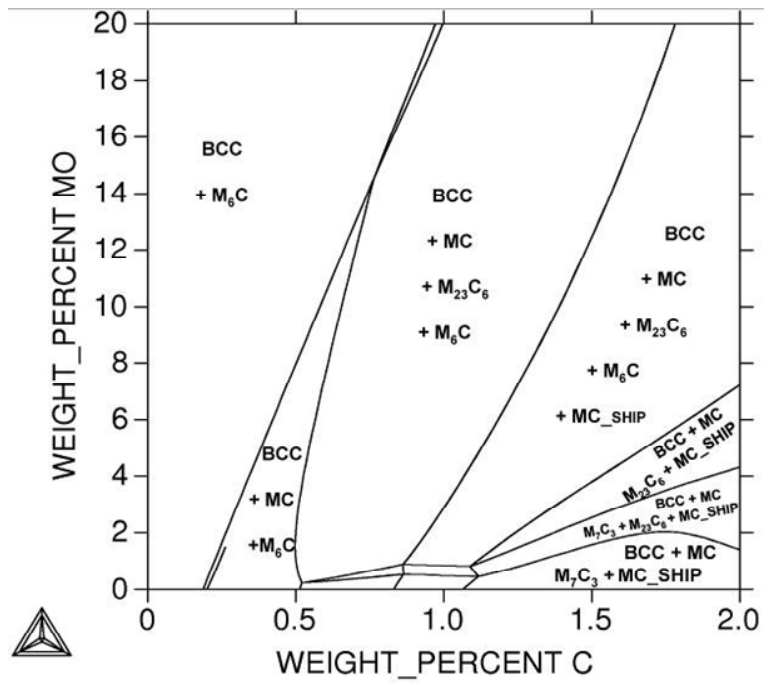

(c)

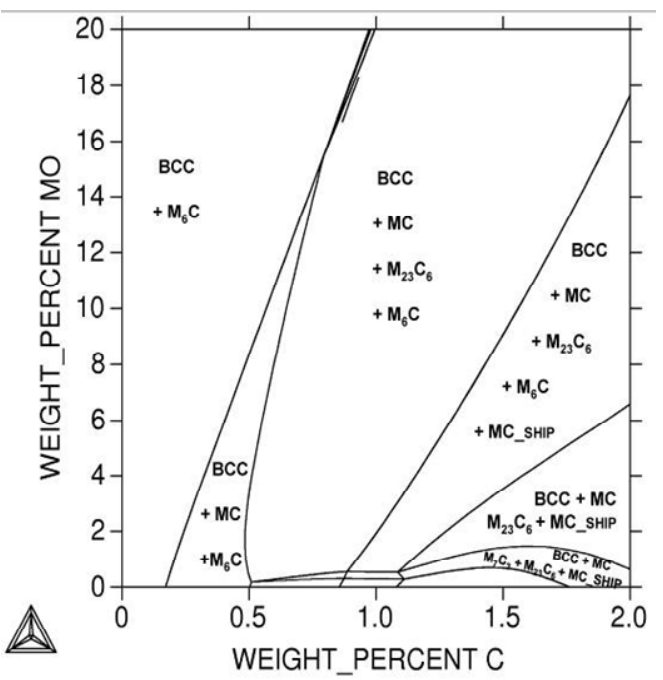

(b)

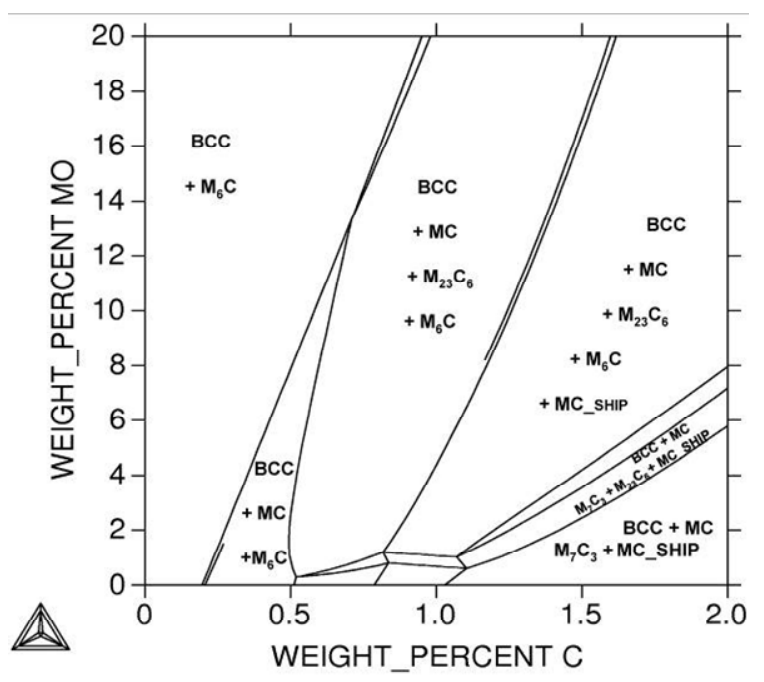

(d)

Figure 7. Portion of the $727^{\circ} \mathrm{C}\left(1000^{\circ} \mathrm{K}\right)$ isothermal section of the Fe-Mo-C system with compositions of investigated steels indicated. (a) Standard M2; (b) $1 \% \mathrm{Si}$; (c) $3 \% \mathrm{Si}$; (d) $5 \% \mathrm{Si}$.

silicon into the alloy has a great effect on the carbides precipitate. This figure shows that increase silicon promotes the formation of $\mathrm{MC}$ and $\mathrm{M}_{6} \mathrm{C}$ type carbides. In additions, decrease in vanadium content or increase in the concentration of carbon in the alloy causes the appearance of $\mathrm{M}_{23} \mathrm{C}_{6}$ or $\mathrm{M}_{7} \mathrm{C}_{3}$ carbides according to the silicon content.

Figure 7 presents a part of the phase diagram of alloys of the Fe-Mo-C system, from which we can infer that the mentioned content of molybdenum (5\%) and carbon (1\%) corresponds to an alloy the carbide phases of which are represented by an $\mathrm{MC}+\mathrm{M}_{6} \mathrm{C}+\mathrm{M}_{23} \mathrm{C}_{6}$ carbides. Increase in the content of silicon in the alloy causes the appearance of MC ship carbides. On the other hand, for more silicon content $5 \% \mathrm{Si}$, the alloy carbide corresponds to purely $\mathrm{MC}+\mathrm{M}_{7} \mathrm{C}_{3}$. Decrease in molybdenum or increase the carbon content leads to precipitate $\mathrm{M}_{7} \mathrm{C}_{3}$ and/or $\mathrm{M}_{3} \mathrm{C}_{2}$ according to the wt $\%$ of both Mo and $\mathrm{C}$.

Figure 8 presents a part of the phase diagram of alloys of the $\mathrm{Fe}-\mathrm{Cr}-\mathrm{C}$ system, from which we can infer that the mentioned content of chromium (4\%) and carbon (1\%) corresponds to an alloy the carbide phases of which are represented by an $\mathrm{MC}+\mathrm{M}_{6} \mathrm{C}+\mathrm{M}_{23} \mathrm{C}_{6}$ carbides. In the case of silicon $1 \%$ to $3 \%$, decrease in the content of chromium and increase carbon content in the alloy causes the appearance of MC_ship carbides. On the other hand, for more silicon content $5 \% \mathrm{Si}$, the alloy carbides correspond to purely $\mathrm{MC}+\mathrm{M}_{7} \mathrm{C}_{3}$. Decrease in chromium or increase the carbon content leads to precipitate MC_ship. So on all content of silicon decrease in chromium and increase in carbon content promotes the formation of $\mathrm{MC}$ _ship carbides. 


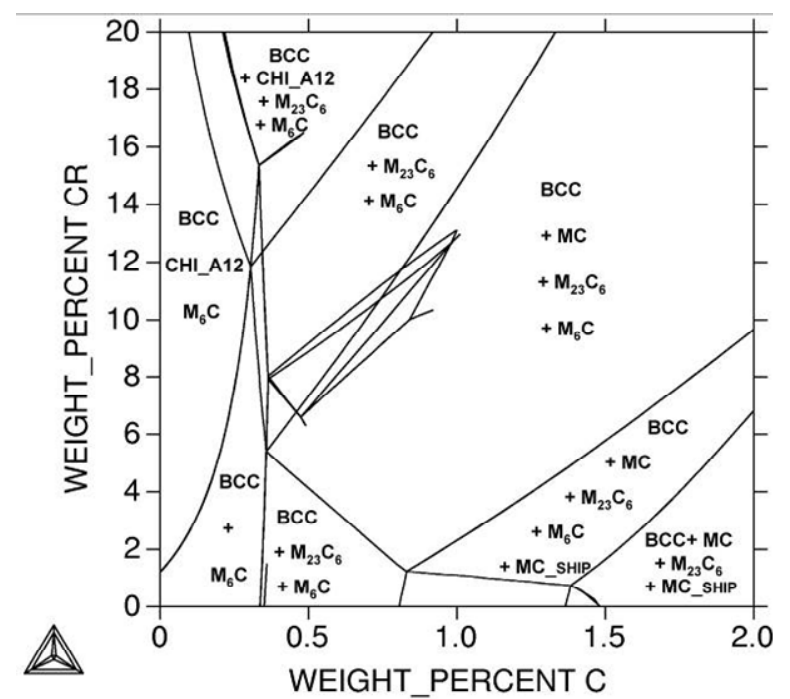

(a)

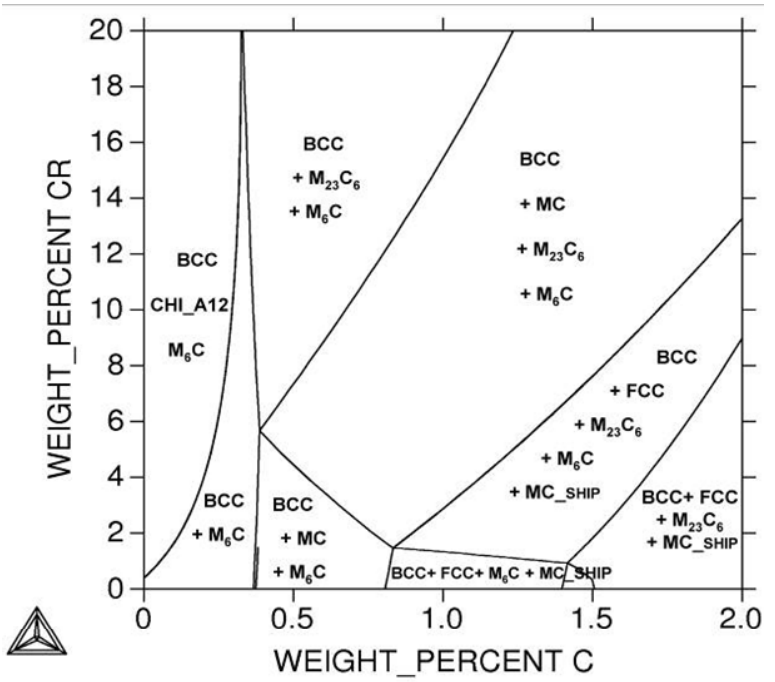

(c)

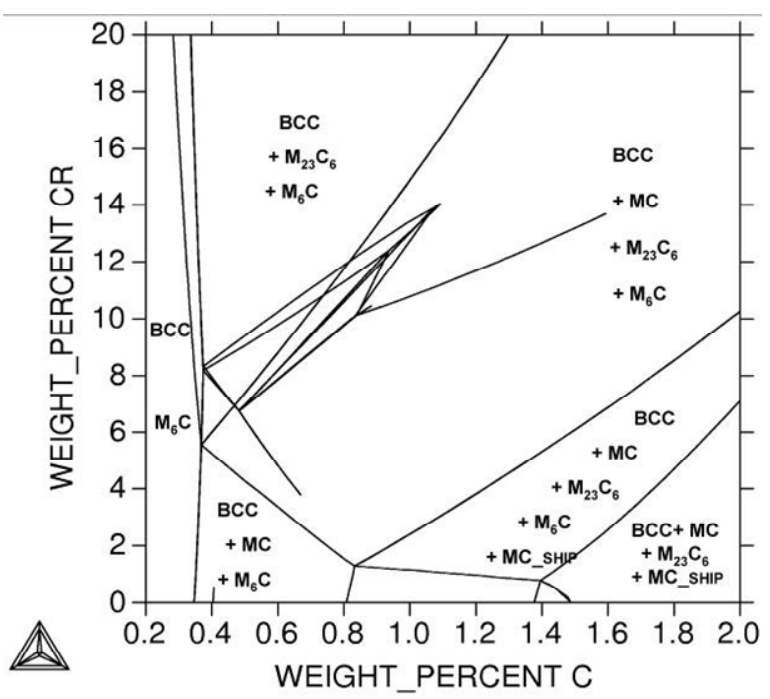

(b)

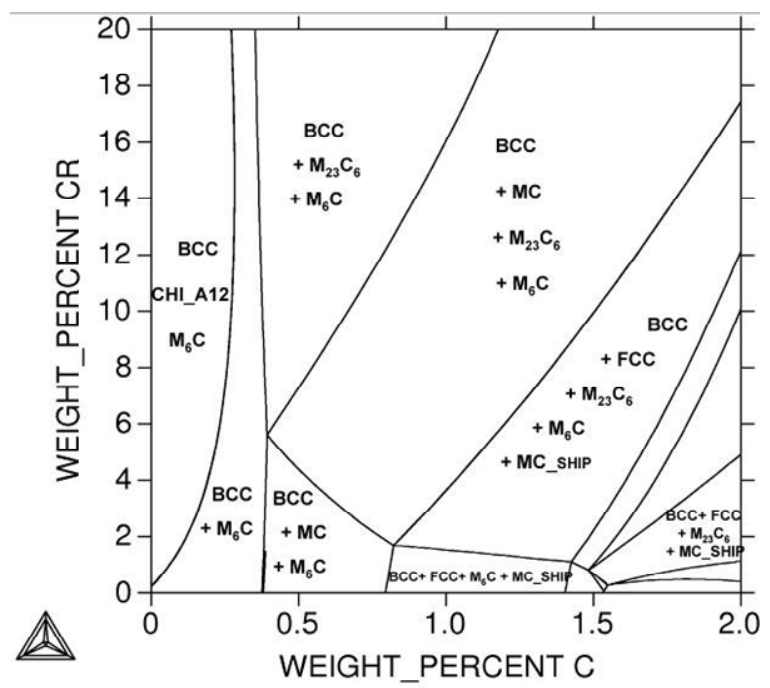

(d)

Figure 8. Portion of the $727^{\circ} \mathrm{C}\left(100^{\circ} \mathrm{K}\right)$ isothermal section of the Fe-Cr-C system with compositions of investigated steels indicated. (a) Standard M2; (b) $1 \% \mathrm{Si}$; (c) $3 \% \mathrm{Si}$; (d) $5 \% \mathrm{Si}$.

It was shown in these Figures 6-8 addition of silicon above $3 \%$ Si promotes the presence of $\mathrm{M}_{7} \mathrm{C}_{3}$ instead of $\mathrm{M}_{23} \mathrm{C}_{6}$ and $\mathrm{MC}$ carbides.

The introduction of chromium (about 4\%) into the investigated steel causes formation of a low amount of iron- and chromium base carbides with composition $\mathrm{M}_{23} \mathrm{C}_{6}$ carbide.

\section{Conclusions}

In the present work, some temperature-concentration diagrams for silicon modified AISI M2 steel are presented by calculated quantities (melting and transformation temperatures, amount and compositions of phases). Calculated data are compared with standard AISI M2 high speed tool steel. The following conclusion can be drawn:
1) The thermodynamic calculations of phase equilibria in silicon-containing high-speed steels give results that are in good agreement with experimental observations on solidification paths, and amounts and compositions of phases. Interpretations of special solidification features which were up to now only hypothetical, have been confirmed by the calculation.

2) The total volume fraction of the silicon containing steel carbides is quite close to standard steel AISI M2. Increase in silicon promotes the formation of $\mathrm{MC}$ and $\mathrm{M}_{6} \mathrm{C}$ type carbides. In additions, decrease in vanadium content or increase in the concentration of carbon in the alloy causes the appearance of $\mathrm{M}_{23} \mathrm{C}_{6}$ or $\mathrm{M}_{7} \mathrm{C}_{3}$ carbides according to the silicon content.

3) The tungsten content of the $\mathrm{M}_{6} \mathrm{C}$ carbides in silicon 
steels is higher than standard steel AISI M2. Growth in the concentration of tungsten in these carbides increases only the mass fraction of these carbides but the volume of these carbides virtually equal.

4) The introduction of silicon into the metal causes formation of a low amount of iron- and chromium base carbides $\left(\mathrm{M}_{23} \mathrm{C}_{6}\right)$ with composition higher chromium content and dissolution of chromium in the $\mathrm{M}_{6} \mathrm{C}$ carbide.

5) The introduction of silicon into the metal causes formation of $\mathrm{MC}$ with largest amount of vanadium and tungsten.

6) Calculations and measurements of phase and carbides confirm that silicon dissolved only in the matrix and totally absence on the carbides but addition of silicon encourage for precipitate carbides with higher alloying element contents.

\section{REFERENCES}

[1] A. P. Gulyaev, "Properties and Heat Treatment of HighSpeed Steel [in Russian]," Mashgiz, Moscow, 1939.

[2] N. A. Minkevich, "Low-Alloy High-Speed Steels [in Russian]," Metallurgiya, Moscow, 1944.

[3] Yu. A. Geller, "Tool Steels [in Russian]," Metallurgiya, Moscow, 1983.

[4] E. C. Bain and H. W. Paxton, "Alloying Elements in Steel," 2nd Edition, ASM, Metals Park, Ohio, 1966, pp. 123-162, 243-247.

[5] M. A. Bayer and A. B. Brucer and V. Teledyne, "High Speed Tool Steels," ASM Handbook, Vol. 16, Machining ASM Handbook Committee, 1989, pp. 51-59.

[6] Y. Geller, “Tool Steels," Mir Publishers, Moscow, 1978.

[7] E. Pippels, J. Woltersdorf, G. Pöckl and G. Lichtenegger, "Microstructure and Nano-Chemistry of Carbide Precipitates in High-Speed Steel S 6-5-2-5," Materials Characterization, Vol. 43, No. 1, 1999, pp. 41-55. doi:10.1016/S1044-5803(99)00003-0

[8] P. Fusheng, H. Mitsuji, L. Yun, D. Peidao, T. Aitao and D. V. Edmonds, "Carbides in High-Speed Steels Containing Silicon," Metallurgical and Materials Transactions A, Vol. 35A, No. 9, 2004, pp. 27-57.

[9] B. Sundman and J. Ågren, “A Regular Solution Model for
Phases with Several Components and Sublattices, Suitable for Computer Applications," Journal of Physics and Chemistry of Solids, Vol. 42, No. 4, 1981, pp. 297-301. doi:10.1016/0022-3697(81)90144-X

[10] H. Halfa, "Characterization of Electroslag Remelted Super Hard High Speed Tool Steel Containing Niobium," Steel Research International, Vol. 84, No. 5, 2013, pp. 495-510. doi:10.1002/srin.201200332

[11] G. F. Vander Voort, "Metallography: Principles and Practice," McGraw-Hill, New York, 1984.

[12] G. Hoyle, "High Speed Steels," Butterworths, London, 1988.

[13] G. C. Coelho, J. A. Golczewski and H. F. Fischmeister, "Thermodynamic Calculations for Nb-Containing HighSpeed Steels and White-Cast-Iron Alloys," Metallurgical and Materials Transactions A, Vol. 34A, No. 9, 2003, p. 1749.

[14] H. Fredriksson and S. Brising, "The Formation of Carbides during Solidification of High-Speed Steels," Scandinavian Journal of Metallurgy, Vol. 5, No. 4, 1976, pp. 268-275.

[15] R. Riedl and H. Fischmeister, "Gerichtete Erstarrung: Eine Methodezur Erforschung des Kristallisationsablaufesbei Stählen," Berg- und Hüttenmännische Monatshefte, Vol. 129, No. 2, 1984, pp. 131-135.

[16] R. Riedl, S. Karagöz, H. Fischmeister and F. Jeglitsch, "Developments in High-Speed Tool Steels," Steel Research International, Vol. 58, No. 3, 1989, pp. 339-352.

[17] H. F. Fischmeister, R. Riedl and S. Karagöz, "Solidification of High-Speed Tool Steels," Metallurgical and Materials Transactions A, Vol. 20A, No. 10, 1989, pp. 2133 2148.

[18] S. Karagöz, I. Liem, E. Bischoff and H. F. Fischmeister, "Determination of Carbide and Matrix Compositions in High-Speed Steels by Analytical Electron Microscopy," Metallurgical and Materials Transactions A, Vol. 20A, No. 12, 1989, pp. 2695-2701.

[19] S. Karagöz and H. F. Fischmeister, "Cutting Performance and Microstructure of High Speed Steels: Contributions of Matrix Strengthening and Undissolved Carbides," Metallurgical and Materials Transactions A, Vol. 29, No. 1, 1998, pp. 205-216. doi:10.1007/s11661-998-0173-3 